\title{
Globalisation and Its Impact on Economic Diplomacy - An Emperical Study of Kuwait
}

\author{
Nasser Redn Thamer Al Motairi, Dr. Abdul Rahman Zaki
}

\begin{abstract}
Globalization is generally defined as the process of integration of nations resulting from the transaction of world views, products, ideas, and many other aspects of culture. One particular development, arising from the advancing globalization, is the way countries are seeking cooperation with other countries of the world. Because of the highly developed means of communication, countries are seeking economic stability through diplomatic relationships. Economic diplomacy is traditionally defined as the decision and policymaking and advocating of business interests of a state. Economic diplomacy requires application of technical expertise that analyzes the effects of one's own and another country's economic situation on its political climate.

This study, therefore, focuses on a historical analysis of the development of globalization and hence, economic diplomacy as one of its resulting trends to determine Kuwait's place in the world economy. The study explores the following research question: What role has globalization played in giving rise to economic diplomacy? The study uses historical analysis to explore the question. Two factors have been important in the current economic situation of the state of Kuwait: its foreign policy which was influenced by the direct interests of Middle Eastern states and of the United States and her dependence on its oil production.
\end{abstract}

Keywords: Economic diplomacy, Globalization, Capital flows, Interdependence of economic and cultural activities

\section{Introduction}

Kuwait has had fundamental importance for USA in last two decades while U.S. has been fighting the menace it faces in Iraq. Because of its location and close cooperation with the United States, Kuwait is vital to U.S. strategies especially because of the diplomatic role it has played in the northern Persian Gulf region after the U.S. forces withdrew from Iraq at the end of 2011. Kuwait's diplomatic ties with the government of Iraq after Saddam Husain's decline have been negatively influenced by very old regional, economic, and political issues still un-solved. These issues have persisted since the Iraqi invasion of Kuwait in 1990, but these issues have now been re-evaluated. Kuwait is not very sure of how her relationship with Iran will hold because they are allies to the US and their efforts would be in the direction of supporting the U.S. efforts in the gulf region. The US is trying to restrain Iranian pressure in the Gulf and stop Iran from exerting undue influence in Iraq after the withdrawal of US forces. Still, Kuwait continues to have fairly normal economic and political relations with Iran so as not to let Iran try stir-up pro-Iranian sentiments in Kuwait.

According to an analysis by Katzman (2012), although the foreign policy of Kuwait has been steady, some political unrest has been observed since 2006. There has been some internal strife between different political groups that represent a group in the National Assembly and the ruling Al Sabah family. The internal strife has essentially been to gain the political and economic ascendancy in the country. The disputes between rival factions of Al-Sabah family have been further exacerbated by the political climate of the country. Owing to these differences National Assembly has been dissolved four times since 2006 followed by four elections, the latest of which was held on February 2, 2012. These elections led to a government that is largely in opposition to Amir Sabah al-Ahmad Al Sabah and has strong Islamist influence. This led Amir Sabah al-Ahmad Al Sabah to suspend the Assembly for one month in 2012. Two days later, this suspension was overturned by a constitutional court ruling. declaring the suspension of the Assembly on December 2011 as unconstitutional and ordered reinstatement of the previous Assembly. Kuwait suffered from political paralysis for many years that caused economic stagnation. The parliament could not approve some major investment projects, such as development of major oil fields in northern Kuwait. This has mainly been due to the internal disputes.

This analysis of Kuwait's political and economic situation highlights the current economical trends and international relations of the country.

"The advancement of the pivotal role of Economic diplomacy in post globalization era is being recognized globally as an important component and tool of foreign relations between the committee of nations. An insight focused on the socio-economic and cultural complexion \&affinities in a particular geographical environment can prove to be a competitive advantage for furthering dedicated business \&economic relations between sovereign states. The acquired awareness can prompt \& trigger customized policy initiatives\& strategies." 
"The compelling need seemingly has been timely identified by visionary vibrant economies resulting in State collaborations, sponsoring of research oriented deliberations with reputed schools of learning so as to be more knowledgeable on the facts which can facilitate, influence and create global business opportunities. Kuwait is actively pursuing similar initiatives in collaboration with the London School Of Economics".

The Kuwait Programme on Development, Governance and Globalization in the Gulf States funded by the Kuwait Foundation for the Advancement of Sciences is a ten year multidisciplinary global research programme. It focuses on topics such as globalization and the repositioning of the Gulf States in the global order, capital flows, and patterns of trade; specific challenges facing carbon and resource-rich economic development; diversification, educational and human capital development into post-oil political economies; and the future of regional security structures in the post-Arab Spring environment.

The Programme is based in the London School Of Economics Department of Government and is directed by Professor Danny Quah, who is also the Kuwait Professor of Economics and International Development. The Programme produces an acclaimed working paper series featuring cutting-edge original research on the Gulf, published an edited volume of essays in 2011, supports post-doctoral researchers and PhD students, and develops academic networks between London School Of Economicsand Gulf institutions.

At the London School Of Economics, the Programme organises a monthly seminar series, invitational breakfast briefings, and occasional public lectures, and is committed to five major biennial international conferences. The first two conferences took place in Kuwait City in 2009 and 2011, on the themes of Globalization and the Gulf, and The Economic Transformation of the Gulf. (www.lse.ac.uk)

Needless to add that the research outcomes would go a long way in facilitating economic initiatives through diplomatic channels.

\subsection{The Phenomenon of Globalization}

The term globalization has recently become common. It is defined as the process of international integration arising from the interchange of world views, products, ideas, and other aspects of culture (AlRodhan and Stoudann, 2006). Particularly, advancements in general transportation and telecommunications infrastructure, economical, agricultural and cultural exchanges programmes including the rise in the Internet use globally, are the major factors in globalization and are considered a cause to interdependence of economic and cultural activities.

One particular development arising from the advancement of globalization is the way countries are seeking cooperation with other countries of the world. Because of the highly developed means of communication, many countries are seeking economic stability by way of diplomatic relationships. This new way of developing trade and economic relations is now known as economic diplomacy. Economic diplomacy is traditionally defined as the decision-making, policy-making and advocating of business interests of a state. This requires application of technical expertise that analyses the effects of one's own and another country's economic situation on its political climate.

\section{Economic Diplomacy}

Economic diplomacy is a somewhat new term that is often used in an imprecise manner. The term 'economic diplomacy' as described by Bayne and Woolcock (2007) is broader in scope and flexible enough to accommodate the needs of the states in the globalized era. Bayne and Woolcock define the scope of economic

\section{Globalization}

Globalization literally means "growth on a global or international scale". The Sociologist Martin Albrow defines globalization as "all those processes by which the peoples of the world are incorporated into a single world society" (1990, p.4).As far as economics and political economy is concerned, there is no specific and inclusive definition of the phenomenon of globalization, but there are many opinions. These opinions have generated several definitions of this phenomenon and all the definitions are subjected to the culture and the tendency of the author. This concept and its various definitions will be discussed at length in Chapter III.

There are two other components of globalization as noted by Robertson, namely, the concepts of individuals and humanitarian. On the basis of these considerations, Robertson formulated a model by tracing the time historical dimension until the current status quo and by dividing it into five stages: (See table 1 on the following page)

Table 1: The Stages of the Development of Globalization Era

\begin{tabular}{|l|l|l|}
\hline Stage & Time Period & \multicolumn{1}{c|}{ Characteristics } \\
\hline $\begin{array}{l}\text { The } \\
\text { embryonic } \\
\text { stage }\end{array}$ & $\begin{array}{l}\text { From the beginning } \\
\text { of } 15 \text { th century to } \\
\text { the } 18 \text { th century }\end{array}$ & $\begin{array}{l}\text { Growth of national societies } \\
\text { Weaker economic restrictions between countries } \\
\text { The deepening of ideas on individual and humanity } \\
\text { The beginnings of crystallization of a central theory of the world }\end{array}$ \\
\hline The & From the mid- & Sharp turn in the idea of homogeneous state \\
\hline
\end{tabular}




\begin{tabular}{|c|c|c|}
\hline $\begin{array}{l}\text { emergence } \\
\text { stage }\end{array}$ & $\begin{array}{l}\text { eighteenth century } \\
\text { to the year } 1870\end{array}$ & $\begin{array}{l}\text { Crystallized concepts of international relations } \\
\text { Crystallization of the concept of citizenship with regard to the individual } \\
\text { Acceptance for the non-European societies in the international community } \\
\text { Interest in the economic collaboration on national and global levels }\end{array}$ \\
\hline $\begin{array}{l}\text { The } \\
\text { launching } \\
\text { stage }\end{array}$ & $\begin{array}{l}\text { From } 1870 \text { to the } \\
\text { twenties of the } \\
\text { twentieth century }\end{array}$ & $\begin{array}{l}\text { The emergence of universal concept of the international society } \\
\text { The emergence of the concepts of nationalism and individualism } \\
\text { The emergence of the ideas of international humanity } \\
\text { An enormous evolution in the number and speed of global forms of contact } \\
\text { The emergence of global competitions like Olympic Games and Nobel Prize } \\
\text { The First World War and the League of Nations }\end{array}$ \\
\hline $\begin{array}{l}\text { The } \\
\text { conflict } \\
\text { stage }\end{array}$ & $\begin{array}{l}\text { From twenties of } \\
\text { the twentieth } \\
\text { century until the } \\
\text { mid-sixties }\end{array}$ & $\begin{array}{l}\text { Intellectual differences on the definition of globalization } \\
\text { Wars and the movements of national liberation } \\
\text { Focus on humanitarian issues } \\
\text { The integration of third world countries in the international community } \\
\text { Escalation of Universal awareness in sixties } \\
\text { The first landing on the moon } \\
\text { The end of the Cold War and the spread of Atomic Weapons } \\
\text { Increased global institutions and global movements } \\
\text { Multiculturalism and multiplicity of breeds within the society itself. } \\
\text { Emergence of civil rights movement. } \\
\text { More liquid international system and end of bilateral system of nationalism. }\end{array}$ \\
\hline
\end{tabular}

\section{Research Approach}

However, the study may be categorized as significant if its main task is seen as being one of the mutual critique, whereby the limiting and alienating conditions of the rank quo are conveyed to inconsequential (Klein and Myers, 1999). In the critical study, the enquiry is classified as emancipative if it aspires to assist eradicated the determinants of unwarranted alienation and domination, and thereby enhance the possibilities for the realization of human promise (Alvessonand Wilmott, 1992; Hirschheim and Klein, 1994). Critical theorists suppose that persons can attentively proceed to change their communal and financial conditions. They furthermore suppose that communal truth is historically constituted and that it is made and duplicated by critical study can be discovered in Ngwenyama and Lee (1997).

\section{Research Method}

For an economic historian, time has always been essentially disconcerting, because neoclassical theory does not take time into account. The neoclassical model is a representation of an instantaneous moment of time and it does not therefore consider how time acts. Without a deep understanding of time, one will be a awful political scientist because time is the aspect of human life on earth that facilitates ideas and institutions and beliefs to evolve. (Douglas North, 1999, p. 316)

On a theoretical map of disciplines, history can be safely positioned at a central place where almost all disciplines gain some common ground and a lot of them are even seen to overlap, philosophically and methodologically. This is because historical studies, in whatever discipline, provide a chronological backbone for all areas of research.

Historical analysis of events helps make sense of the meaning of those events in retrospect. In historical analysis, past events are systematically examined to give an account from a particular perspective and it involves interpretation to recapture the nuances and ideas that influenced these events. (Elana, Akrivi, Costas, Georgios and Constantin, 2009). The purpose of this analysis is to recreate the past, through existing records and their interconnections to the present events.

Pierson (2004) defines historical analysis as investigation in temporal processes that allows us to identify and explicate some fundamental mechanisms, social, political or economic. By mechanism, what is meant here is "plausible, frequently observed ways in which things happen" (Elster, 1989, p. viii).

According to Amenta (2009) the historical thinking has provided new insights, "such as a focus on path dependence and time order in explanations" (p. 351) and, new tools, such as formal qualitative techniques for historical sociologists and historical institutionalists in political science (Pierson and Skocpol, 2002). Scholars from a variety of area shave studied the historical impact of events as they lead to certain phenomena or more decisive events. However, there aren't many examples of top-down historical analyses carried out for the purpose of understanding the different policy developments or trends in thinking in the field of economics. Scholars in the field believe that economists and other social scientists need to engage in debates in historiography and often assess historical materials independently. There may be selection problems and biases that come with the background in another discipline and even a comprehensive knowledge of the secondary sources on a given subject may be insufficient (Amenta, 2009).

It is therefore suggested that in studying historical examples, it is usually helpful to combine observation with an evolving theory - to identify the likely key factors and relationships among factors early in order to be better able to "see" and interpret historical cases with some sophistication (Edwards, 2000). 


\section{Literature Review}

In the name of free market, oil related industries were made vulnerable to corporate sectors and left little room for indigenous policy control against the rampant globalization. Anti globalization put forward the argument that it hurts the poor. The reason behind the argument is that the manufacturer and producers of the less developed countries have to compete with highly organized competitors of the West and Far East. On the other hand the pro globalization views that the growing world consumption could only meet through free market mechanism in which products are available at affordable prices to all consumers and open competition will offer perfect competition among the producers and manufacturers.

Literature is available on both views but in this study our focus will remain on the selected sectors. Governments' data banks provide a rich source on the topic both quantitative and qualitative. Besides, independent studies from various aspects of globalization are also available in abundance. In addition to that international NGOs, corporate businesses and their association also maintain good size material on the production and business growth in the country. Globalization is still debated at various levels that whether it is really helpful in eradicating poverty or vice versa. This debate is reflected in following two quotations:

Martin Wolf believes that "a world integrated through the market should be highly beneficial to the vast majority of the world's inhabitants"; whereas the International Forum on Globalization concludes that "the globalization is the rising tide that will lift all boats, as proclaimed by it promoters, but it is only lifting yachts".

\section{Dimensions of Globalization}

There are many dimensions of globalization, but mostly important and prominent are: economic, political, social and cultural dimensions.

\section{Economic Dimension}

This is the most important dimension, so much so that many theorists used it as a starting point for analysis of the phenomenon of globalization. The principles of economic dimension of globalization on several universal bases as articulated by the General Agreement on Tariffs and Trade (GATT), as follows:

- Freedom of international trade, removal of barriers towards the flow of goods and services and transfer of capital.

- Reduction of custom tariffs.

- The globalization of production and marketing.

- Increase of multinational enterprises in the global economy.

- Increase in the role and importance of the three pillars of globalization; International Monetary Fund (IMF), World development Bank and the World Trade Organization (WTO).

- The emergence of great economic blocks.

- The integration of companies and banks.

- Growing role of Foreign Direct Investment (FDI) in the world economy in general and in developing countries in particular.

\section{Effects of Globalization}

Even when we analyze the effects of globalization on aspects other than the economy of a country, we see visible impact on social, cultural and political constructs of a country. This does not mean that the relationship between globalization and poverty is trivial while studying the economy of the Gulf region. Globalization also influences the process of workers' migration from one country to another. As one visible consequence we have the example of Gulf and Kuwait hosting considerable number of workers from the less developed countries of the region. In this way, the region of Gulf has contributed indirectly in the fight against poverty in those countries. The changing nature of host state's society, demography and public policies are areas which have not yet gained due attention in academic research.

Proponents of globalization argue that fast growing global markets prioritized efficiency and competitiveness criteria. However, research has generated some data that reject this claim. Mishra (1999) and many others claim that in the number of OECD countries openness spread retrenchment in welfare programs but not in others. A consensus has been seen on the point that such countries have labor market institutions that can dampen the negative effects of globalization. Although some scholars have recently begun to investigate the ability of LDC governments to resist RTB pressures and maintain or increase existing levels of social spending in developing countries, the extant literature does not sufficiently explain why, in a globalizing economy, the politico economic conditions affecting welfare spending might differ from developed countries and as a result, render such nations more susceptible to RTB pressures (Wibbles, 2006).

Given the location of Kuwait is safe and distinguished by the virtue of a strategic site on the shore of the sea on one hand, and ease of contact with the desert on the other hand. Kuwait has become the Head 
Quartersand a center for large and diverse gatherings of the various Arab tribes UtubAnsaan who shifted from their places of origin in the Arabian Peninsula during the early $17^{\text {th }}$ century and then proliferated in the middle of the century.

Various tribes settled in the growing region of Kuwait and engaged themselves in business and trade activities. They traded in goods and items such as sugar, coffee, spices and textiles and transported the same along the northern corridor to the city of Aleppo including the merchant fleet of Alexandria of the various countries of Europe.

The people of Kuwait were also actively engaged with the activities of navigation and transportation, commercial fishing and pearl diving, in addition to the practice of grazing cattle and camel breeding, which, as defined by the elite was a "life in the region of Kuwait concentrated all in between the exploitation of the sea and desert in the transportation, trade and diving and pearl finding activities as well as fishing sole from the Gulf".

Accordingly, Kuwait continued its progress and growth and developed to become a big prestigious and grand city of the Northern Gulf. On account of the commercial activities, Kuwait enriched its economy. Its trade networks expanded all over the concerned areas. Kuwait became center of multifarious business and trade activities.

The city experienced a marked proliferation of population and extensive construction of buildings and roads, mosques and sky scrapers which added to the glory of the grand city which made industrial progress with industries Kalhaddadp, dying, construction, sewing and knitting industries which included the works on tents and ponchos with sewing and knitting machines, knives, hammers and demolition machinery as well as pots, boilers and other appliances.

\section{The Modern History of Kuwait}

Yousuf bin Issa in his famous book 'Pages from the History of Kuwait' has written that the first inhabitants (occupants of Kuwait) were Al-Sabah and their group who were Nomads and fishermen and they along with Al Khalifa, Zayed and Jalahma and recidivism gradually migrated to Kuwait after obtaining due permission from Governor Bani Khalid. The migration was followed by several other Persians and Arabs.

The English East India Company delegates residing in the Arabian Gulf region witnessed that the rulers of this region in the eighteenth century were the descendents of the Bani Khalid called "Adnaniyah".Since the seventeenth century, the rule of Bani Khalid had continued in the East of Arabian Peninsula but at the end of eighteenth century, the Government of Kuwait wrested control form the Ottoman governors.

\section{Chronology, History and Rulers of theAl Sabah}

\begin{tabular}{|l|l|}
\hline The name of the Ruler & Period of Ruling \\
\hline Sheikh Sabah Bin Jaber (Sabah Al Awal) & $1752-1776$ \\
\hline Sheikh Abdullah Al Sabah (Sabah Al Awal) & $1776-1814$ \\
\hline Sheikh Jaber Al Sabah (Jaber Al-Aish) & $1814-1859$ \\
\hline Sheikh Sabah Al Sabah & $1859-1866$ \\
\hline Sheikh Abdullah II Al Sabah & $1866-1891$ \\
\hline Sheikh Mohammad Al-Sabah & $1891-1896$ \\
\hline Sheikh Mubarak Al Sabah (Mubarak the Great) & $1896-1915$ \\
\hline Sheikh Jaber II Al Sabah & $1915-1917$ \\
\hline Sheikh Saleem Al Sabah & $1917-1921$ \\
\hline Shaeikh Ahmad Al-Jaber Al-Sabah & $1921-1950$ \\
\hline Sheikh Abdullah III Al-Saleem Al-Sabah & $1950-1965$ \\
\hline Sheikh Sabah Al-Sabah Al-Sabah, the Third & $1965-1977$ \\
\hline Sheikh Jaber III Al-Ahmad Al- Sabah & $1977-2006$ \\
\hline Sheikh Saad Al-Abdullah Al-Saleem Al-Sabah & 2006 \\
\hline Sheikh Sabah IV Al-Ahmad Al-Sabah & 2006 \\
\hline
\end{tabular}

\section{Conclusion}

Economic diplomacy is now a common strategy to develop and sustain international relations. The richer a country gets, the more politically stable the rulers are but this is only possible by having a strong economy accompanied by social justice. These two things reinforce good governance and can be achieved by way of a robust economic policy for diplomats to follow. For a few decades now all Asian countries have set about on the course of economic diplomacy for some years and have seen an improvement in economic relations with other countries also with an increased volume of trade to their benefit. For example in 2004, Indo-China trade allegedly increased from a meager amount of few millions a few years earlier to US\$13 billion. During the Cold War, there were no armed conflicts and it was regarded a success. However, as 21 st century dawned, the definition of success changed. Interactions through economic diplomacy to enhance country's economic gains in today's globalized and competitive world are the criteria. 
The economy of Kuwait needs to looked at in the perspective of small states as well as those of the Muslim countries. Rana (2007, p.202-205) discusses the ingredients of a successful economic diplomacy and what is missing in the small economies that need to be attended to from the point of view economic diplomacy.

\section{References}

[1]. Ajija, S. R. andKusreni, S. (2011). Globalization and Socio Economic Welfare of Muslim Countries A Case Study of Indonesia and Malaysia. European Journal of Social Sciences 25 (3) (2011), pp. 329-343.

[2]. Al-Rodhan, Nayef R.F. and Stoudmann, G. (2006). Definitions of Globalization: A Comprehensive overview and a proposed definition. Geneva Centre for Security Policy, Geneva. Retrieved from: http://www.sustainablehistory.com/articles/definitions-ofglobalization.pdf

[3]. Albrow, M. (1990). Introduction. In Martin Albrow and Elizabeth King (Eds) Globalization, Knowledge and Society: Readings from International Sociology, 1-12. London: Sage.

[4]. Alvesson, M. and Willmott, H. (1999). On the idea of emancipation in management and organization studies.Academy of Management Review, 17 (3), 1992b, 432-464.

[5]. Amenta, E. (2009). Making the most of an historical case study: Configuration, sequences, casing and the US old-age pension movement. In Byrne and Charles C. Regin (Eds), Sage Handbook of Case-based Methods, 351-366. London: Sage Publications.

[6]. Andrzej, K. (2003). The changing status of Arab migrant in the GCC. Journal of Social Affairs, 20 (7), $42-50$.

[7]. Appadurai, A. (2001). Grassroots globalization and the research imagination. In Arjun Appadurai (Ed.), Globalization (a public culture book), 1-21.London: DukeUniversity Press.

[8]. Al Zu'abi, Ali. (2004). Modern urbanization in Kuwait.Journal of Social Affairs, 21 (8), 13-30

[9]. Berridge, G.R. and James, A. (2003). A dictionary of diplomacy. NY: Palgrave Macmillan.

[10]. Battalio, J. (2002). A methodology for streamlining historical research: The analysis oftechnical and scientific publications. IEEE Transactions on Professional Communications, 45 (1), 21-39.

[11]. Bayne, N and Woolcock, S. (2007): What is economic diplomacy? In N. Bayne; S. Woolcock (Eds) The new economic diplomacy: decision-making and negotiation in international economic relations, 2nd ed. 1-20. Aldershot: Ashgate.

[12]. Beck, U. (2003). What is globalization. Malden, MA: Blackwell Publishing.

[13]. Berridge, G.R. and James, A. (2003). A dictionary of diplomacy. Palgrave Macmillan

[14]. Bruce, J. (2010). Mead and organizational learning: Gaining organizational momentum in the $21^{\text {st }}$ century. Organizational Management, Vol. 15(4), 290-329

[15]. Bull, H. (1995). The anarchical society.New York: Columbia University Press Caplan, B. and Cowen, T. (2004). Do We Underestimate the Benefits of Cultural.The American Economic Review, 94, (2), 402-407.

[16]. Drake, S. (2011). Transformational servant leadership: Leading through example. Leadership Journal, Vol. 23, 455-587. doi: 21./34297.

[17]. Edwards, Sean J.A. (2000). Swarming on the battlefield: Past, present and future. Santa Monica: RAND Corporation.

[18]. Einstein, A. (2005). The meaning of relativity (Brian Green ed.). Princeton, NJ: Princeton University Press. (Original work published 1922).

[19]. Elana, T., Akrivi, K. ,Costas, V., Georgios,, L. and Constantin, H. (2009). Capturing the historical research methodology: An experimental approach. Proceedings of International Conference of Education, Research and Innovation, Madrid, November 1618, 2009. Retrieved from: http://hci-vr.cst.uop.gr/papers/\%5BC54\%5D HistoricalResearchMethodology.pdf

[20]. Elster, J. (1989). Nuts and Bolts for the Social Sciences. Cambridge, UK: Cambridge University Press. 